\title{
Suppressing miRNA-15a/-16 expression by interleukin- 6 enhances drug-resistance in myeloma cells
}

\author{
Mu Hao ${ }^{1}$, Li Zhang², Gang An', Weiwei Sui', Zhen Yu', Dehui Zou', Yan Xu ${ }^{1}$, Hong Chang ${ }^{3}$ and Lugui Qiu*
}

\begin{abstract}
The bone marrow microenvironment facilitates the survival, differentiation, and proliferation of myeloma (MM) cells. This study identified that microRNA-15a and -16 expressions tightly correlated with proliferation and drug sensitivity of MM cells. miRNA-15a/-16 expression in MM cells was significantly increased after treatment with cytotoxic agents. The interaction of bone marrow stromal cells (BMSC) with MM cells resulted in decreased miRNA-15a/-16 expression and promoted the survival of the MM cells. Interleukin-6 (IL-6) produced by BMSCs suppressed the expression of miRNA-15a and 16 in a time- and dose- dependent pattern, with the suppression on miRNA-15a being more significant than on miRNA-16. miRNA-15a-transfected MM cells were found to be arrested in G1/S checkpoint, and the transfected MM cells had decreased growth and survival. In conclusion, our data suggest that via suppressing miRNA-15a and -16 expressions, IL-6 secreted by BMSCs promotes drug-resistance in myeloma cells.
\end{abstract}

\section{To the Editor}

Multiple myeloma (MM) is an incurable plasma cell malignancy [1-3]. Binding of MM cells to bone marrow stromal cells (BMSCs) promotes the growth, survival, metastasis and drug resistance of the MM cells. The molecular bases of MM progression and drug resistance remain incompletely understood $[4,5]$. In this study, apoptosis analysis by flow cytometry showed that BMSCs protect U266 and NCI-H929 myeloma cells from apoptosis induced by melphalan and bortezomib. (Figure 1A). IL-6 and VEGF are critical growth factors for myeloma cells. Both are mainly produced by BMSCs [6-8]. By ELISA analysis, we found that the level of IL-6 and VEGF secreted in the supernatant of BMSCs derived from MM patient (MM-BMSCs) was significantly higher $(188.8+9.4 \mathrm{pg} / \mathrm{mL}$ and $1497.2+39.7 \mathrm{pg} / \mathrm{mL}$, respectively) than that of normal BMSCs $(115.0+15.1$ $\mathrm{pg} / \mathrm{mL}$ and $1239.0+21.1 \mathrm{pg} / \mathrm{mL}$, respectively; $\mathrm{p}<0.05)$.

microRNA $-15 \mathrm{a}$ and -16 are located on chromosome 13, an area commonly deleted in MM. Deletion of chromosome 13 predicts a significantly reduced survival in

\footnotetext{
* Correspondence: drqiu99@medmail.com

${ }^{1}$ State Key Laboratory of Experimental Hematology, Institute of Hematology \& Blood Diseases Hospital, Chinese Academy of Medical Science \& Peking Union Medical College Tianjin China

Full list of author information is available at the end of the article
}

patient with MM [9-11]. We thus focused on the functions of miRNA-15a and -16. We found that miRNA15a/-16 expression in MM cells was significantly increased under melphalan and bortezomib treatment (Figure 1B). Moreover, dexamethasone sensitive MM cell line, MM1S, expressed higher level of miRNA-15a than the resistant MM1R. miRNA-15a expression in MMIS and MM1R was $909.73 \pm 7.12$ and $134.88 \pm$ 19.85 ( $\mathrm{p}<0.01)$, respectively, and miRNA-16 expression in those cells was $9.83 \pm 2.01$ and $9.20 \pm 3.81$ ( $>$ > 0.05), respectively. Interestingly, the interaction of MM cells with MM-BMSCs inhibited miRNA-15a and -16 expressions in MM cells. (Figure 1B) IL-6 secreted by MMBMSCs decreased expression of miRNA-15a and -16 in myeloma cells in a time- and dose- dependent pattern. (Figure 1C,D) The suppression on miRNA-15a was more significant than on miRNA-16 in myeloma cells. Previous study has identified cyclinD1, cyclinD2 and CDC25A as the targets of miRNA-15a [12]. Our data further showed that miRNA-15a-transfected MM cells were arrested in G1/S checkpoint. The over-expression of miRNA-15a inhibited growth and survival of the transfected MM cells.

In conclusion, this study identified that microRNA$15 \mathrm{a}$ and -16 expressions correlated well with proliferation and drug sensitivity of MM cells. MM-BMSCs

\section{(O) BioMed Central}




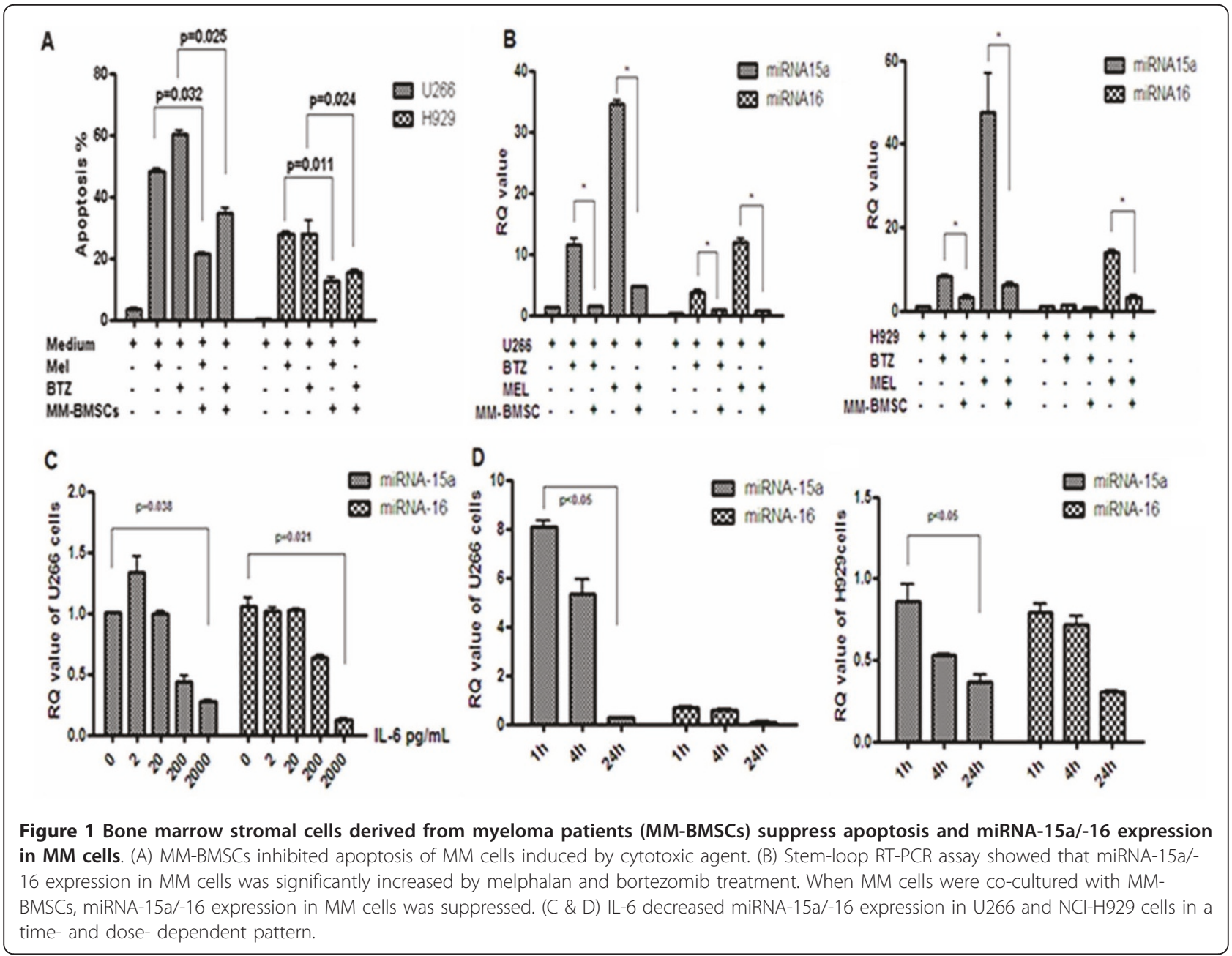

enhanced the survival of the MM cells and protected them from drug-induced apoptosis by suppressing miRNA-15a/-16 expression. IL-6 secreted by the MMBMSCs plays a pivotal role in this process.

\section{List of Abbreviation}

MM: multiple myeloma; BMSCs: bone marrow stromal cells; IL-6: interleukin 6; VEGF: Vascular-Endothelial Growth Factor; ELISA: enzyme-linked immunosorbent assay

\section{Acknowledgements}

This work was supported in part by grants from the National Natural Science Foundation of China (30871095 \& 81172255). Tianjin Science and

Technology Supporting Programme (09ZCGYSF01000) and Foundation for Youth Researcher of CAMS \& PUMC.

\section{Author details}

${ }^{1}$ State Key Laboratory of Experimental Hematology, Institute of Hematology \& Blood Diseases Hospital, Chinese Academy of Medical Science \& Peking Union Medical College Tianjin China. ${ }^{2}$ West China Hospital, Sichuan University. Blood Section, Chengdu, Sichuan, China. ${ }^{3}$ Department of Laboratory Hematology, University Health Network, University of Toronto, Canada.

\section{Authors' contributions}

$\mathrm{MH}$ provided the concept and design of the study, acquisition of data, analysis and interpretation of data, drafting the manuscript; $L$ Zh and GA performed myeloma cell Stem-loop RT-PCR assay; WWS, DHZ collected samples from myeloma patients; $Z Y$ and $Y X$ assisted in data collection; $\mathrm{HC}$ and $L G Q$ revised the manuscript and gave final approval of the version to be submitted. All authors have read and approved the final manuscript.

\section{Conflicts of Interests}

The authors declare that they have no competing interests.

Received: 24 August 2011 Accepted: 22 September 2011 Published: 22 September 2011

\section{References}

1. Richardson $P G$, Barlogie B, Berenson J, Singhal S, Jagannath $S$, Irwin D, Rajkumar SV, Srkalovic G, Alsina M, Alexanian R, Siegel D, Orlowski RZ, Kuter D, Limentani SA, Lee S, Hideshima T, Esseltine DL, Kauffman M, Adams J, Schenkein DP, Anderson KC: A phase 2 study of bortezomib in relapsed, refractory myeloma. N Engl J Med 2003, 348:2609-2617.

2. Mitsiades CS, Mitsiades N, Munshi NC, Anderson KC: Focus on multiple myeloma. Cancer Cell 2004, 6:439-444.

3. Johann Micallef, Moyez Dharsee, Jian Chen, Suzanne Ackloo, Ken Evans, Luqui Qiu, Hong Chang: Applying mass spectrometry based proteomic 
technology to advance the understanding of multiple myeloma. Journal of Hematology \& Oncology 2010, 3:13.

4. Jiahuai Tan, Shundong Cang, Yuehua Ma, Petrillo LRichard, Delong Liu: Novel histone deacetylase inhibitors in clinical trials as anti-cancer agents. Journal of Hematology \& Oncology 2010, 3:5.

5. Venumadhav Kotla, Swati Goel, Sangeeta Nischal, Christoph Heuck, Kumar Vivek, Bhaskar Das, Amit Verma: Mechanism of action of lenalidomide in hematological malignancies. Journal of Hematology \& Oncology 2009, 2:36.

6. Raab SMarc, Klaus Podar, Iris Breitkreutz: Multiple myeloma. Lancet 2009, 374:324-339.

7. Hardin J, MacLeod S, Grigorieva I, Chang R, Barlogie B, Xiao H, Epstein J: Interleukin-6 prevents dexamethasone-induced myeloma cell death. Blood 1994, 84:3063-3070

8. Mahindra A, Hideshima T, Anderson KC: Multiple myeloma: biology of the disease. Blood Rev 2010, 24(Suppl 1):S5-11.

9. Anuradha Budhu, Junfang Ji, Wang WXin: The clinical potential of microRNAs. Journal of Hematology \& Oncology 2010, 3:37.

10. Roccaro AM, Sacco A, Thompson B, Leleu X, Azab AK, Azab F, Runnels J, Jia X, Ngo HT, Melhem MR, Lin CP, Ribatti D, Rollins BJ, Witzig TE, Anderson KC, Ghobrial IM: MicroRNAs 15a and 16 regulate tumor proliferation in multiple myeloma. Blood 2009, 113:6669-6680.

11. Fonseca R, Blood E, Rue M, Harrington D, Oken MM, Kyle RA, Dewald GW, Van Ness B, Van Wier SA, Henderson KJ, Bailey RJ, Greipp PR: Clinical and biologic implications of recurrent genomic aberrations in myeloma. Blood 2003, 101:4569-4575.

12. Lee SO, Masyuk T, Splinter P, Banales JM, Masyuk A, Stroope A, Larusso N microRNA15a modulates expression of the cell-cycle regulator $\mathrm{Cdc} 25 \mathrm{~A}$ and affects hepatic cystogenesis in a rat model of polycystic kidney disease. J Clin Invest 2008, 118:3714-3724.

doi:10.1186/1756-8722-4-37

Cite this article as: Hao et al:: Suppressing miRNA-15a/-16 expression by interleukin-6 enhances drug-resistance in myeloma cells. Journal of Hematology \& Oncology 2011 4:37.

\section{Submit your next manuscript to BioMed Central} and take full advantage of:

- Convenient online submission

- Thorough peer review

- No space constraints or color figure charges

- Immediate publication on acceptance

- Inclusion in PubMed, CAS, Scopus and Google Scholar

- Research which is freely available for redistribution

Submit your manuscript at www.biomedcentral.com/submit
C Biomed Central 